\section{Culprit found at Cornell}

\section{Washington}

BLAME for a computer 'worm' that crippled thousands of installations on the Internet computer network last November has been placed squarely on the shoulders of Robert Tappan Morris by a commission of inquiry at Cornell University, where Morris is a graduate student.

The attack raised many questions about the security of computer networks to unwarranted entry. But according to the Cornell inquiry, made public late last month, Morris's actions did not so much represent "an heroic event that pointed up the weaknesses of operating systems" as "a juvenile act that ignored the clear potential consequences".

The worm was released on 3 November, 1989 and infected computers using particular versions of the UNIX operating system (see Nature 336, 97; 1988). Although it was first diagnosed as a computer 'virus', the infecting program is more properly known as a worm, as it does not require another computer program to act as a 'host' to carry it from one machine

\section{COMPUTERS}

\section{Pakistani virus invades Indian neighbour}

\section{New Delhi}

'C-Bran', a computer virus of Pakistani origin, has hit personal computers throughout India in what is thought to be the first epidemic of its kind in the nation. The incident highlights India's extensive trade in pirated software and copied floppy disks.

In just four weeks, 'C-bran' showed up in computer schools and a private company in Bangalore and in some 20 companies in Bombay, including an international bank. The virus was also reported from Madras, Kanpur and Vijayawada, a small town where 750 of 1,000 floppy disks used by a private company were found to be infected. Scientists at the Delhi University Computer Centre said their machines were invaded by the 'ashar' variant of the virus.

Dr N. C. Kalra of the Indian Institute of Technology in Delhi, who detected 'ashar' in the institute's computer, centre blamed the epidemic on pirated software. No virus has yet shown up in computers linked by electronic networks but government agencies have been alerted. India's NICNET links the Cybercomputer mainframe computer in the Planning Commission with portable computers in district headquarters while another network, ERNET links the computer centres of eight educational institutions. The six major commercial computer networks all claim to have strengthened their security system following the epidemic. K.S. Jayaraman

\section{to another.}

According to the inquiry's findings, the worm consisted of two parts; a 99-line 'probe' written in the ' $\mathrm{C}$ ' programming language, and a much larger 'corpus' that had been compiled into machine language. If the probe was able to get into a computer, it sent for its larger body. The probe used four basic methods to gain entry. Two used specific design features of UNIX mail programs that allowed the worm to enter a new machine without passwords that would normally be required. Another avenue was essentially a sophisticated guessing game in which the worm exploited a human tendency to choose simple passwords related to account names. A fourth method exploited a design feature of UNIX that allows people to use the same password on several different machines where they have accounts.

After releasing the worm on the evening of 3 November, Morris evidently decided he had made a mistake, and asked an associate at Harvard to send a message to computer users around the country telling them how to protect themselves against the worm. But the warning was sent by a slow method, and arrived after others had discovered the worm and developed ways to defeat it.

The commission concluded that several thousand computers were infected by the worm, but thousands more had to be shut down as a precaution to prove that infection had not occurred.

The commission points out that Morris was able to exploit security flaws in the UNIX operating system but that UNIX was never designed to be a secure system and many of the flaws were already well known. The commission concluded that creating the worm required "dedication and perseverance rather than technical brilliance", adding that Morris "displayed naive conceit in assuming that he could launch an untested, unsimulated, complex worm onto a complex network and have it work correctly the first time".

Morris declined to be interviewed by the commission of inquiry on the advice of his counsel, but from talking with his colleagues and friends and by examining logs of Morris's computer activities, the commission concluded that Morris alone had written the worm.

Although the commission recommends strong disciplinary action, it suggests that the discipline "should not be so stern as to damage permanently the perpetrator's career". Cornell University has not yet decided on any punishment for Morris. An investigation of the incident by the Federal Bureau of Investigation has not yet resulted in any indictments.

Joseph Palca

\section{Britain to expand?}

\section{London}

BrITAIN has played only a minor role in Arctic research until now, with total funds from the research councils of little more than $£ 1.5$ million last year. The Natural Environmental Research Council (NERC) now wants to change this, so that Britain can act at least as a useful partner in international research programmes.

Last year, NERC spent less than $£ 500,000$ on Arctic research, mostly on individual research grants and training awards; there are no institutional research programmes devoted to the Arctic. NERC has now asked for an additional $£ 2$ million a year from next year's science budget for Arctic research.

The council has rejected the suggestion that it create an Arctic research institution with permanent research bases comparable in size to those in the Antarctic. "On political and financial grounds", this would be unrealistic, it says in its first strategy document for the Arctic, published this week. Less ambitiously, it wants to build a small base on Svalbard, the archipelago north of Norway. The base would be intended to house about 20 researchers and to cost only $£ 70,000$ to build and $£ 50,000$ a year to run.

The council also wants to increase support for the Scott Polar Research Institute at the University of Cambridge. With more staff and increased and secure long-term funds, this institute would become the focus of British Arctic research, says Dr John Bowman, secretary of the council. But he stresses that expansion here will not compromise research elsewhere in the country. Research areas to which the council gives priority are meteorology, solar-terrestrial physics, oceanography, glaciology, ecology, geology, socio-economic sciences and engineering.

\section{SPACE SCIENCE}

Christine McGourty

\section{Explorers selected}

\section{Washington}

The National Aeronautics and Space Administration (NASA) last week announced the first four in a series of small scientific missions that will be launched on existing expendable launch vehicles. The small scale missions - with total costs for each spacecraft expected to average $\mathbf{\$ 3 0}$ million -are intended to provide research opportunities for a new generation of space scientists and engineers.

The four projects, chosen out of 51 applications, include the Solar, Anomalous and Magnetospheric Particle Explorer, the Submillimeter Wave Astronomy Satellite, the Fast Auroral Snapshot Explorer and a global ozone satellite that will carry a total ozone mapping spectrometer. Joseph Palca 